\title{
XV. Observations on spiders, and their supposed poison
}

\section{Amoreux jun. M.D.}

To cite this article: M. Amoreux jun. M.D. (1800) XV. Observations on spiders, and their supposed poison, Philosophical Magazine Series 1, 6:21, 74-80, DOI: 10.1080/14786440008677190

To link to this article: http://dx.doi.org/10.1080/14786440008677190

Published online: 18 May 2009.

Submit your article to this journal $₫$

Џ Article views: 2

Q View related articles $\sqsubset$ 
of wonl and greafe, held down by a plate of metal faftened by ferews. $i$ is a plate of copper, concare, or rather conical below, Atretching almoft to the fide of the ftill; $m$ a large hole in the centre of this plate, through which the fteam generated at the bottom of the fill efcapes into the head. This plate, being made of quick afcent, facilitatrs the cfcape of the fteam, which might otherwife be partially accumnlated under the ftoulder of the ftill, and, by its re-action on the fubcumbent liquor, caufe the ftill to run foul, or boil over. $k k$ the head of the ftill. To the foraping-machine $f$ are attached chains, which, by the rotary motion of the fcraper, are dragged with rapidity nver the whole of the bottom, by which means the wan is prevented from burning to the bottom, and thereby generating any new compound injurious to the flavour or quality of the fpirit. Thefe tills are ufually of from 40 to 50 gallons contents.

The principle of the improvement ferms to centre in this fimple point-The greater the quantity of heat that can be made to pafs through the body of the fill in a given time, the greater will be the quantity of vapour, and confequently of fpirits, produced in that time: and certainly it is not eafy to conceive how this can be attained in any way fo effectually as by making the fill all bottom, as it were, and applying the heat to every part of that bottom.

XV. Obfervations on Spiders, and their fieppofial Paifon. By M. AHOREUX jun. M. D. *

$\mathrm{T}$

HIS genus of infects is as numerous in fpecies as the latter are varied. France contains almoft the half of the fpecies known. M. Geoffroy has mentioned only fixteen; but Dr. Lifter, who made obfervations of the fane kind in England, and M. Clerk, who earried them as far as any one in Siveden, have given a more complete hiftory of them. Scopoli, fo commendable in other refpects for his ufeful sabours, does not appear to have dore right in changing entrely the denomination of forty-four fpecies of fpiders, which he faw

* From Notice des Infeles de la France reputés venimeux. 
in Carniola, merely that he might have the pleafure of giving to each the name of fome illuftrious perfon who has promoted the fcience of entomology. This mark of honour is of little confequence to fuch great Mecenases, and the inconvenience of increafing and confufing the received nomenclature is very great.

The public care litle alfo for the exact defcriptions of naturalifts, and their methodic claffifications. They require facts; fomething wonderful and extraordinary. They wifh that every natural being flould prefent fome new phenomenon; an objest of immediate utility, or a fubject of reprobation: and when their prejudices are once eftablifhed, nothing can deftroy them. Sometimes, for the truth muft be confeffed, naturalifts in their writings have been the fource of errors and prejudices. Were we to correct the affertions of Pliny, Johnfton, Monfet, and Aldrovandi, authors ftill quoted, and which one cannot read with patience, refpecting infects only, we fhould make a large book of controverfies, which would ferve neither to inftruct the learned, nor to undeceive the people, always wedded to their ignorance.

The hiftory of fpiders, and that of the effects of their renom, were it properly treated, would alone furnifh matter for an ample chapter. What variety in the fenfations of man! Some have an invincible averfion to fpiders; and there are women who faint at the bare mention of their name*: others treat them with familiarity, and think it an

* This antipatly is no lefs ftrong, though often more reafonable, arrong the men. M. Zimmerman relates the following fingular inftance of it, to which he was a witnefs: - "Being one day in an Englin company," firs he, "couffiting of perfons of diftuetion, the convergation happened in till upon antipathics The grester part of the company denied the reahty of them, and trated them as oid women's tales; but I told them that antipathy was a real difeale. Mr. Willium Matthew, fon of the governor nt Barbatoes, was of my apinion; and, as he adued that he had himfelf in extreme antipathy as forders, he was laughed at be the whole company.

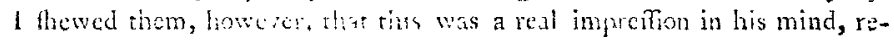
iditing from a nechamcal wetet. Mr. John Murray, afterwards Duke of Athol, touk is into his head to make, in Mr. Matthew's prefence, a fpider of bhack wax, to try whether this antipathy would appear mercly on a fint of the infice. He weat on of the room, therefore, and retumed with 
act of prowels to eat them. So many things have been related for and againt the affertion of fpiders being venomous, that we cannot but be cautious in regard to what has been faid on the fubject by different authors; we muft therefore requeft thofe who relate fuch ftories in future, to give a correct defcription of the kind of fpider or other infect which they believe to be poifonous, together with their common and fcientific names, which will remove all doubt and confufion.

Our fpiders in France are in general rather ugly than formidable. If there are any fufpected of being poifonous, it ought not to be the domeftic fpider with long claws, aranea parientina and aranea pbalangiodes Linn. nor the mower of the fields, phalangium opilio Linn, the only kinds of the phalangia mentioned by Geoffroy; nor the mafon fpider, with which perhaps this author was unacquainted, becaufe it inhabits the fouthern provinces; nor the orange-coloured fpider, and that entirely white aranea vidtica, and the aranca citrina Linn. found commonly among vegetables and fruit, and chiefly grapes; nor fo many others which we fee daily,

a bit of black wax in his hand, which he kept fhut. Mr. Matthew, who in other refpeets was a fedate and amiable $m / n$, inagining that his friend really held a fpider, immediately drew his fword in a great fury, retired with precipitation to the wall, leaned againft it as if to run him through, and fent forth horrible cries. All the raffeles of his face were fivelled, his eye-balls rolled in their fockets, and his whole body was as ftiff as a polt. We immediately ran to him in great alarm, and took his fword fion him, affuring him at the fame time that Mr. Murray had nothing in his hand but a little wax, and that he mighe himfelf fee it on the table, where it was placed.

He remained fome time in this fpaímodic fate, and I was really afraid. of the confequences. He however gratually recovered, and deplored the dreadful pafion into which he had been thrown, and from which he fill fuffered. His pulfe was exceedingly quick and full, and his whole body was covered with a cold fweat. After taking a fidative he was reftored to his former tranquillity, and his fear was attcuded with no other bad confequences. We muft not be furprifed at this antipathy : the larift and moft hideous fijters are found in Barbadoes, and MT. Natthew was born in that illand. Scmo one of the company having tormed of the farne wax, in his prefence, imali frider; he looked at it while making with the utmoft tranquillity, but it would have been impotntle to induce him to conch itw Fo was not, however, of a timid difpoftion." 
and of which we have no caufe to complain. If all our fpiders were noxious, how many accidents would daily happen in houfes which are not kept clean, and to thofe people who labour in the fields? In that cafe it would be highly proper to deftroy them.

The brown, black, and hairy fpiders, which refide in vaults and cellars, as they infpire the contagious air of dirty and uninhabited places, may have juices capable of doing hurt when they are bruifed by accident on any naked part of the body, or introduced into the ftomach. Of this, however, we have no well-attefted proofs, though we know that the hairy fpider is mifchievous, and that it attacks even wafps, the fcales of which it breaks with its ftrong forceps. But what fhall we think of the popular opinion, that fpiders lofe their venom in certain privileged places? This is related of the old tower of Parifet at a league from Grenoble, fituated on a mountain, and called by the populace Tour Saint Verain, to exprefs the tower without poifon *; where, as is faid, no ferpent, fpider, or venomous animal is to be found: we are even affured, that thofe carried thither immediately die.

Spiders have often attracted the attention of the curious by their manceuvres, their amours, and fingular mode of copulation, as well as by their addrefs in fpinning their webs, and forming cods, in which they inclofe their eggs; on account of their art in repairing the accidents which happen to their webs, and the breaches they make in them on purpofe to deliver themfelves from too ftrong a captive they have entangled; and of their perpetual wars, and the carnage they occafion, \&c. Thefe are the actions not of mere au-

* John Tardif, a phyfician, who wrote in 1618 , fpeaks very feriouny of the tower without venom, as one of the wonders of Dauphiny. M. Lancelot, who reduced all the wonders of this province to their juft value in a memoir upon this fubjed inferted among thofe of the Academy of Infcriptions and Belles Lettres, Vol. VI. fays, that the tower without renum is no longer worthy of that nanse. It is falfe that no venomous animals live near it; ferpents and fpiders are found there, is well as in other places "I have feen fome carried thither," fays M. Lancelot, "for the fake of experiment, and it did not appear that they found themfelves incommoded by the change." 
tomata, and which muft aftonifh thofe who view them with the eye of a philofopher.

A worthy magiftrate, M. Bon, who was fond of natural hiftory, at a time when it was neceffary to furmount many prejudices, found means to breed fpiders, and to extract filk from their cods, which he opened. All fpiders are not weavers, but they are fpinners, and all live by hunting. This hunting, for the mott part, is only ftationary, like that by decoy. Thefe hunters difplay confiderable cunning and addrefs to make their prey fall into the fnares which they have laid. One kind, the aranea domeftica, extends its net horizontally in a corner, hooks itfelf to it, and in that manner lies in wait for its prey; another, the aranea dumetorum, places its net in a vertical pofition acrofs an alley in a garden, to intercept the pafling infects; one conceals itfelf in its cavern, and darts forth on the fmalleft noife; and another fufpends itfelf from the branch of a tree by a long thread, and acts the tumbler, to attract ftupid fpectators. There are fome which cover their cave on the outfide with a kind of white filk, as if to announce, by a beautiful entrance, that there will be no danger to proceed farther : this is merely a decoy. Such is their occupation, their refources, and their induftry. As in every numerous race there are vagabonds, fome fpiders employ themfelves only in running about, and in jumping. Such are the habits of the wolf fpider. There are fome allo exceedingly cruel, which employ their arms with great force and activity.

The ftructure of fpiders is no lefs remarkable than their habits. They have always eight eyes, but differently difpofed; and this has enabled naturdifts to divide them into different claffes, in order that they may be better diftinguithed. M. Fabricius, however, has made known five fpecies with only fix eyes. This is denied by M. Geoffroy, who apparently had not feen thefe fpecies. But the mof interefting organ in thefe infects is their mouth, fince it is with this alone that they are able to hurt us. The mouth of the fpider confifts of two ftrong forceps, terminated by a kind of very tharp clav's, the points of which are bent 
downwards*. Thefe forceps or claws are moveable, and can eafily be turned upwards or downwards, and even from right to left. It is with thefe inftruments that the fpider feizes, pinches, and kills its prey. The points alfo ferve it as a mouth : though their extremity is very fharp, it is pierced towards the end ; and the infide of the forceps is hollow; fo that the fpider by thefe means fucks up the moifture of flies, or of other infects which it feizes.

Swammerdam fays, that what might be taken for teeth in the fpider are real ftings or darts with which it pierces thofe animals the blood of which it fucks: but this obferver did not believe that the fpider emitted from thefe darts a venomous liquor. Lifter, who fays he had certain proofs of fpiders being venomous, expreffed the poifon from thefe inftruments. Leuwenhoek alfo advances, that the venom of the fpiders is contained in the cavity of the harp pincers which proceed from the mouth of the infeet. Others have faid that thefe forceps are not hollow, but that the venom proceeds from a fmall trunk which iffues from the mouth at the moment when the infect feizes its prey. It is poffible, and even probable, that different kinds of fpiders have a different organifation; and it is a certain fact, that many fpiders, and perhaps all of them, throw out from their mouth a certain liquor, with which they moiften their prey. We may reft affured, however, that our fpiders have nothing in them of a venomous nature; and this is proved by our fo often touching them without danger. They are often between our teeth when we eat fruit and certain kinds of vegetables, yet we perceive no other bad confequences from them than thofe which may arife from fear and the idea of dirtinefs. There are even fpider-eaters, who make a fport of fwallowing them: fome do it through whim, others through a depraved tafte, and fome to thew their courage, or to gain a wager $t$. Redi

* This defcription is according to Geoffroy, Vol. III. p. 63 . Thore of Linneus and Fabricius are as follows: Aranea. Os unguibus fo retisaculis drobis. Palpi dus arriculati, Linn. Aranea. Labium breove, apice rosundatum. Palpi duo incurni, maris clatati. Fabric.

+ Inftances of Spider-eaters may be found in the Ephemerides of the Searches into Nature, the Philofophical Tranfactions, and in Vanderwiel, who has collected a great many from different authors. 
faw people who ate fpiders, and, from the experiments whicf he made, he does not belicve them to be poifonous. Dr. Fairfax is of the fame opinion. Clerk and Roëfel maintain, that fpiders are not fo venomous as is fuppofed, fince many perfons fwallow them. It is rclated by the Peintre Naturalifle, that a man pretty far advanced in life ate all the fpiders which he found, and that they ferved him as a purgative. He fpread them on a llice of bread, as if they had been excellent marmalade. The fame naturalift confutes the popular error, that the fpider is able, by its pricking, to kill the toad. He faw nothing of the kind, though he made various experiments on that fubject.

[To be concluded in the next Number.]

XVI. Some Account of the late Mark Eleazar Bloch, of Berlin.

$\mathrm{M}$

ARK ELEAZAR BLOCH, a Jewifh phyfician eftablifhed at Berlin, and well known by his Natural Hiftory of Finhes, was born at Anfpach, in Franconia, of very poor parents. His father, who was exceedingly devout, fpent his whole time in reading the Bible and the Talmud; while his mother, by felling old clothes, and other things of the like kind, gained enough to maintain her hufband and children. M. Bloch, at the age of nineteen, could not read German, and did not knuw a fingle word of Latin. He had read only a few Rabbinical books, and fpoke a kind of Franconian gibberifh mixed with the Judaic jargon. A Jewilh furgeon, fettled at Hamburgh, having taken him into his houfe to inftruct his children, he learned good German by hearing the gazettes read, and afterwards by fudying the language. $\mathrm{He}$ lived fo economically that he faved from his fcanty falary as much as enabled him to pay for infruction in the Latin, which he was taught by a ftudent as poor as himfelf. $\mathrm{He}$ acquired, at the fame time, fome knowledge of furgery; and, as he had relations at Berlin, he repaired to that city to ftudy anatomy. Having furmounted various difficulties, and got himfelf admitted as Doctor in the Univerfity of Francfort, 